\title{
Phytophthora infestans induced defense response in calli of wild and cultivated potato genotypes: Pathogen induced cell death in cultures - a marker for resistance
}

\author{
Aruna Kumari, N. ${ }^{1}$, Veena S. Anil ${ }^{1 *}$, B. T. Krishnaprasad ${ }^{2}$ \\ ${ }^{1}$ Department of Plant Biotechnology, University of Agricultural Sciences, GKVK, Bangalore 560065, India \\ ${ }^{2}$ Department of Agricultural Biotechnology, College of Agriculture, Hassan 573225, India
}

\author{
Article history \\ Received: 02 July 2017 \\ Accepted: 18 July 2017 \\ Published: 22 July 2017
}

(C) Aruna et al. (2017)

\section{Editor}

K K Sabu

Publisher

Horizon e-Publishing Group

Correspondence

Veena S. Anil

$凶$ veenaanil@ymail.com

\begin{abstract}
Late Blight caused by Phytophthora infestans (Mont.) de Bary is the most destructive foliar disease causing $30 \%$ yield losses in the potato (Solanum tuberosum L.) crop globally. Wild potato genotypes AC1 and AC4, and potato cultivar Kufri Girdhari are highly resistant, whereas wild genotype AC6, and cultivars Kufri Chandramuki and Kufri Jyoti are susceptible to Late Blight. In the current study, the calli of these six potato genotypes were used to understand the mechanism of cellular resistance to Late Blight. Exposure to P. infestans or its elicitors significantly induced peroxidase (POX) and superoxide dismutase (SOD) activities, and induced accumulation of phenolics and flavonoids, indicating the capability of the calli cells to mount a defense response. The study is the first to report the extracellular secretion of defense enzymes, SOD and POX when cells encounter the pathogen, implicating a similar whole-plant phenomenon of enhanced defense in the apoplast. Interestingly, the calli of resistant genotypes showed poor survival upon exposure to pathogen or when grown on elicitor medium, while the susceptible genotypes showed better survival. The percentage of calli cells accumulating intracellular $\mathrm{H}_{2} \mathrm{O}_{2}$ was high in resistant genotypes, and directly correlated with the observed higher cell death. The study shows that $\mathrm{H}_{2} \mathrm{O}_{2}$ accumulation in the cells of resistant genotypes is indeed self-destructive, a whole plant phenomenon termed hypersensitive response - cell death at site of infection. The potato callus system thus can be used to gain new insights into the plant-defense response to $P$. infestans.
\end{abstract}

Keywords: Potato; Late Blight; resistance; callus; peroxide; cell death

Aruna, K. N., V. S. Anil, and B. T. Krishnaprasad. 2017. Phytophthora infestans induced defense response in calli of wild and cultivated potato genotypes: Pathogen induced cell death in cultures - a marker for resistance. Plant Science Today 4(3): 105-120. http://dx.doi.org/10.14719/pst.2017.4.3.319

\section{Introduction}

The cultivated potato (Solanum tuberosum L.) is one of the world's principal food crops and is a tetraploid (4n). Late blight, a devastating foliar disease, caused by Phytophthora infestans is the major biotic constraint in potato cultivation leading to an annual loss in yield of 30\% globally. The pathogen was named Phytophthora infestans, the Greek words for 'plant destroyer'.
Plants have several constitutive and inducible features that can protect them against infection by fungal and other pathogens. The induced defense mechanisms of plants include reactive oxygen species, phytoalexins, and other toxic, non-proteinaceous molecules, cell wall fortifications, defense-related enzymes and induced cell death (Heath, 2000). Reactive oxygen species (ROS) play a pivotal role in defense mechanisms of plants against 


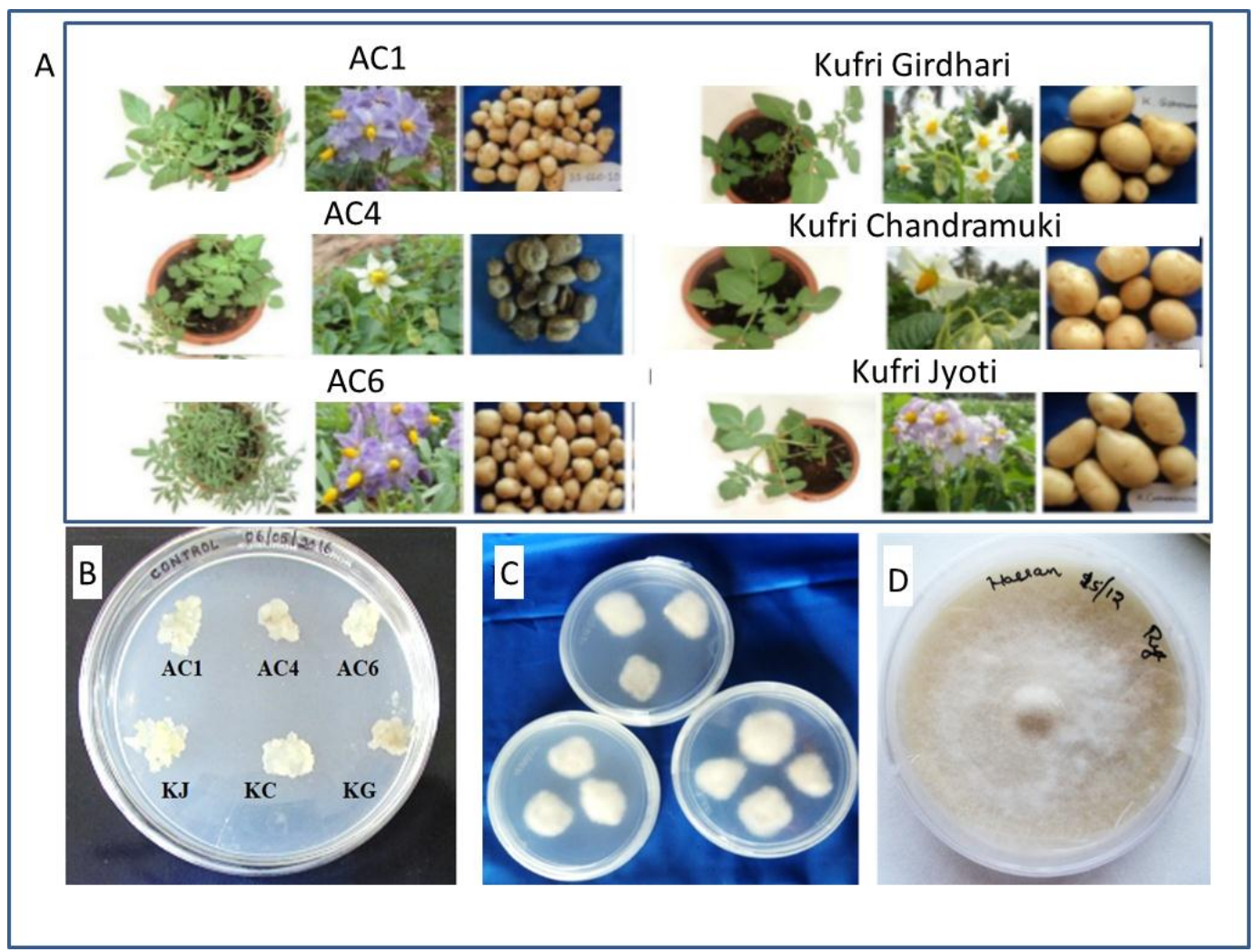

Fig. 1. Biological material used in this study: A. Wild and cultivated genotypes of potato; B. Leaf derived Calli of the six potato genotypes; C, Phytophthora infestans (ACH 1) isolate maintained on potato slices; C. Phytophthora infestans (ACH 1) isolate on Rye agar medium.

Table 1: Potato genotypes from which calli was derived for this study

\begin{tabular}{clclcc}
\hline $\begin{array}{c}\text { Sl. } \\
\text { No. }\end{array}$ & \multicolumn{1}{c}{ Genotype } & $\begin{array}{c}\text { Referred } \\
\text { name }\end{array}$ & Species Name & Ploidy & Late Blight \\
\hline 1 & Kufri Jyoti & KJ & Solanum tuberosum & $4 n$ & Susceptible \\
\hline 2 & Kufri Girdhari & KG & Solanum tuberosum & $4 n$ & Resistant \\
\hline 3 & Kufri Chandramuki & KC & Solanum tuberosum & $4 n$ & Susceptible \\
\hline 4 & SS-660-10 & AC1 & Solanum chacoense & $2 n$ & Resistant \\
\hline 5 & SS-1724-07 & AC4 & Solanum sparsipillium & $2 n$ & Resistant \\
\hline 6 & SS-1725-54 & AC6 & Solanum spegzinii & $2 n$ & Susceptible \\
\hline
\end{tabular}

$\left(\mathrm{H}_{2} \mathrm{O}_{2}\right)$ are examples of ROS that can cause the oxidative destruction of cells (Asada and Takahashi, 1987). Oxidative burst is a phenomenon that occurs at the site of infection due to the rapid accumulation of ROS (Lamb and Dixon, 1997) and can lead to a hypersensitive response (HR) that results in host cell death, which prevents further spread of biotrophic pathogens (Heath, 2000; Gechev et al., 2006). ROS can also serve as second messengers for the activation of specific defense signaling pathways that can prevent disease (Dat et al., 2000; Grant and Loake, 2000).

Plant resistance mechanisms are associated with up-regulation or down-regulation of oxidative enzymes such as superoxide dismutase, catalase, and peroxidase (Chaman et al., 2001; Heng-Moss et al. 2004). These studies suggest that the increase in levels of peroxidases were a response to enhanced levels of endogenous peroxide. Oxidative enzymes are highly correlated with defense mechanism in resistant plants.

Earlier, nine genotypes of potato, six wild species (Solanum chacoense genotypes - AC1, AC2; Solanum sparsipillium genotypes AC3, AC4, AC5 and genotype of Solanum spegzinii, AC6) and three cultivars Kufri Jyoti (KJ), Kufri Chandramukhi (KC), and Kufri Girdhari (KG) obtained from CPRI, Shimla were screened for their resistance to Late Blight in lab and field experiments for over three years. Two of the wild species, AC1, AC4 and cultivar KG showed high degree of resistance against Late Blight disease in detached leaf assays and in three years of field evaluations (2012-2014). AC6, KC and KJ were susceptible to Late Blight. The resistant wild genotypes exhibited horizontal resistance (Anil et al., 2013; Anil et al., paper communicated).

This research was undertaken to evaluate cellular defense mechanisms in susceptible and resistant genotypes of potato using the callus system 
as an experimental model. Calli generated from three potato genotypes resistant to Late Blight, AC1, AC4 and KG, and three genotypes susceptible to Late Blight, AC6, KJ, KC, were selected for this study. The study characterizes an in vitro callus model system for the study of cellular defense mechanism and the interactions of the potato $-P$. infestans host pathosystem.

\section{Materials and Methods}

\section{Biological materials}

Callus of potato genotypes: Callus cultures derived from leaves of three genotypes of wild species (AC1, AC4 and AC6) and three cultivars (KJ, KC and KG) of potato (Table 1) were earlier generated as per the tissue culture procedure developed by Anil and coworkers. In brief, callus was generated from surface sterilized leaves of potato genotypes on Murashige and Skoog (MS) medium (Murashige and Skoog, 1962), supplemented with $1 \mathrm{mg} \mathrm{l}^{-1}$ 2,4Dichlorophenoxyacetic acid (2, 4-D) and $1 \mathrm{mg} \mathrm{l}^{-1}$ Benzyl amino purine (BAP). The callus induced at the cut edges of leaf discs was subcultured into MS medium containing $2 \mathrm{mg} \mathrm{l}^{-1}$ 2, 4-D for further callus proliferation and maintained in the same medium, till further experimentation. Fig. 1 shows the six genotypes of Potato and the respective calli.

Phytophthora infestans isolates: $P$. infestans from Late Blight infested potato leaves was isolated earlier from fields at the College of Agriculture, Hassan (Anil et al., 2013). Pure culture of $P$. infestans was maintained both on potato slices and on Rye medium and used for further experiments in this study. The Rye medium was prepared using Rye seeds according to the procedure described by Caten and Jinks (1968).

Preparation of Phytophthora infestans culture filtrate (CF): Rye broth, $100 \mathrm{ml}$, was inoculated with two mycelial plugs $\left(0.25 \mathrm{~cm}^{2}\right.$ each) of freshly grown $P$. infestans grown on solid rye agar media. The flasks were incubated at $18^{\circ} \mathrm{C}$ with slow shaking (110 $\mathrm{rpm}$ ) in a temperature-controlled orbital shaker for 30 days. The medium was separated from the mycelia by filtering through sterile filter paper (Watman 1) under vacuum. The medium was then centrifuged at $10000 \mathrm{rpm}$ for $30 \mathrm{~min}$ and the supernatant filter sterilized.

Preparation of Phytophthora infestans for experiment: $P$. infestans was maintained on rye agar media for two weeks. Freshly produced sporangia were collected into distilled water, concentration of sporangial suspension adjusted to $2 \times 10^{4}$ sporangia ml-1 and kept at $4^{\circ} \mathrm{C}$ for one hour to release zoospores and used for further experiment.

\section{Experimental setup}

Cellular defense response of calli cells of six genotypes grown on phytopathotoxic medium: Phytopathotoxic medium was prepared by adding culture filtrate (CF) of $P$. infestans to MS medium in $10,20,30 \%$ concentrations. The experiments was carried out with four treatments as follows:

\begin{tabular}{cl}
\hline Treatments & Description \\
\hline $\mathrm{C}_{0}-$ & Control (MS medium) \\
\hline $\mathrm{C}_{1}-$ & MS medium containing $10 \% \mathrm{CF}$ \\
\hline $\mathrm{C}_{2}-$ & MS medium containing $20 \% \mathrm{CF}$ \\
\hline $\mathrm{C}_{3}-$ & MS medium containing $30 \% \mathrm{CF}$ \\
\hline
\end{tabular}

The calli were allowed to grow for 25 days on the phytopathotoxic medium and then evaluated for viability and defense response parameters.

Cellular defense response of calli exposed to Phytophthora infestans or its elicitors: The calli of six genotypes were exposed to $P$. infestans or its elicitors for a period of 24 hours and defense response, secreted protein analysis and cell death was monitored.

\begin{tabular}{cl}
\hline Treatments & \multicolumn{1}{c}{ Description } \\
\hline $\mathrm{T}_{0}-$ & Control (callus alone) \\
\hline $\mathrm{T}_{1}-$ & Callus + Phytophthora infestans (PI) \\
\hline $\mathrm{T}_{2}-$ & $\begin{array}{l}\text { Callus + Diffusible elicitors (PI inside a } \\
\text { dialysis bag) }\end{array}$ \\
\hline $\mathrm{T}_{3}-$ & Callus + Culture filtrate (elicitors of PI) \\
\hline
\end{tabular}

Evaluation of cell viability: The viability of callus cells exposed to the different treatments was estimated by dye exclusion method using Trypan Blue vital stain. A packed cell volume (PCV) of 200 $\mu \mathrm{l}$ calli derived suspension cells were suspended in liquid MS media in a microfuge tube and placed in a rotary shaker for 10-20 min. After centrifugation at $4000 \mathrm{rpm}$ for $5 \mathrm{~min}$, the medium was discarded. $100 \mu \mathrm{l} 0.4 \%$ Trypan Blue stain was added and placed again in rotary shaker for 10 min to allow the cells to take up the stain. The cells were washed and observed under the microscope $(10 \mathrm{x})$. The nuclei of dead cells were stained Blue. The viability of cells was calculated by counting the dead cells in five microscopic fields. Per cent cell death was calculated as per the method described in Anil et al., 2007.

Enzyme extraction from callus: Calli from different treatments were frozen in liquid nitrogen to prevent proteolytic activity and homogenized using pestle and mortar. The homogenate was then suspended in extraction buffer (Phosphate buffer $0.1 \mathrm{M}, \mathrm{pH}$ 7.8, $1 \mathrm{mM}$ PMSF and $0.1 \%$ poly venyl pyrollidone] and held on ice for $15 \mathrm{~min}$. The protein extracts were centrifuged at $14,000 \mathrm{rpm}$ at $4^{\circ} \mathrm{C}$ for $30 \mathrm{~min}$. The pellet was discarded and the supernatant containing the soluble proteins was used for further experiments. Protein level was estimated by the method of Lowry (1951) using BSA as standard.

Sample preparation and sample loading: Soluble protein extract from the samples of each treatment 


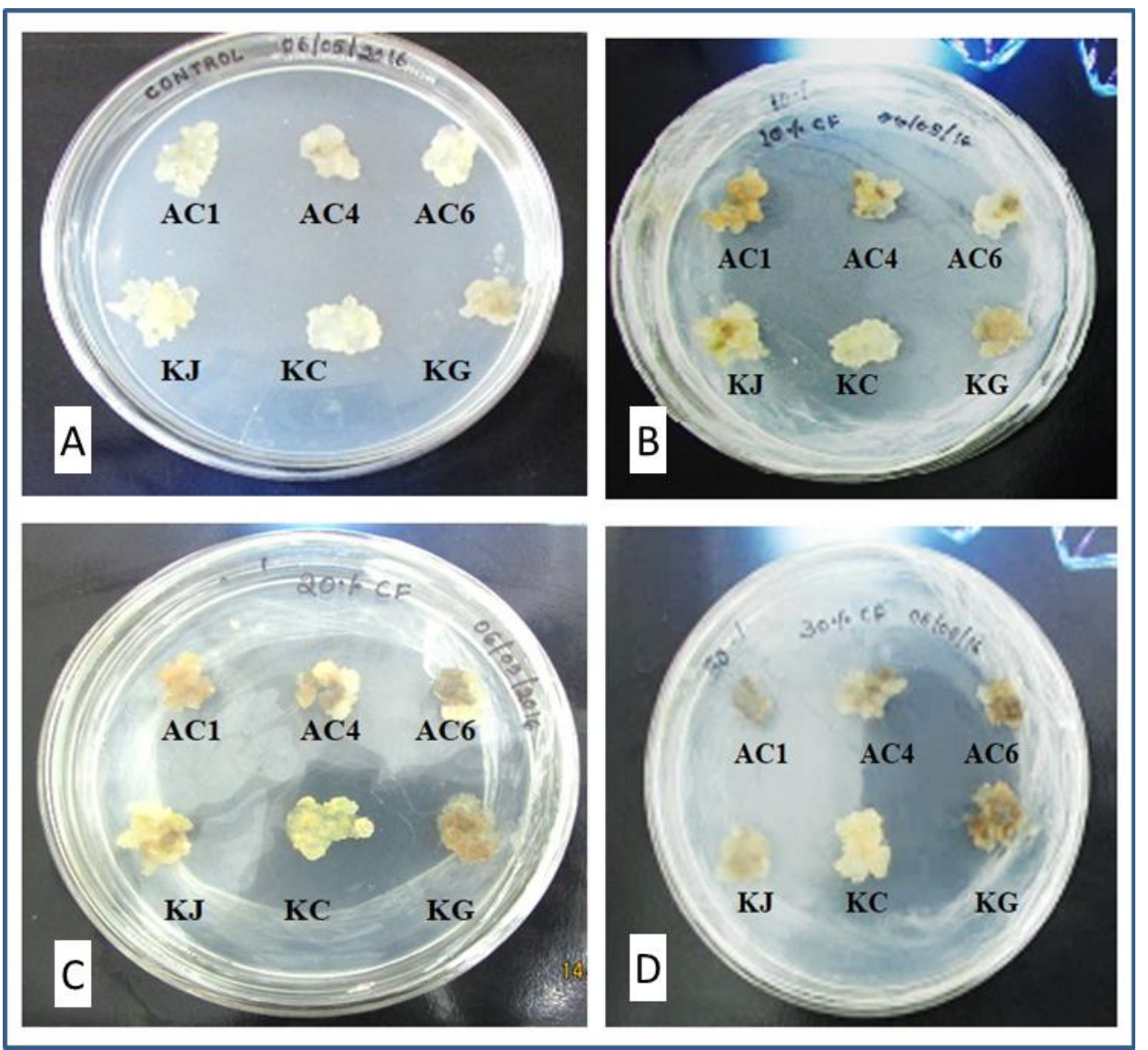

Fig. 2. Calli of six potato genotypes grown on phytopathotoxic medium. A. Control, $\mathrm{C}_{0}$; B. 10 per cent CF, $\mathrm{C}_{1}$; C. 20 per cent CF, $\mathrm{C}_{2}$; D. 30 per cent $\mathrm{CF}, \mathrm{C}_{3}$

Table 2: Effect of phytopathotoxic medium on calli cell survival

\begin{tabular}{|c|c|c|c|c|c|}
\hline \multirow{2}{*}{ Genotypes } & \multicolumn{4}{|c|}{ Cell Mortality (\%) } & \multirow{2}{*}{ CD@1\% } \\
\hline & $\mathrm{C}_{0}$ & $\mathrm{C}_{1}$ & $\mathrm{C}_{2}$ & $\mathrm{C}_{3}$ & \\
\hline AC1 & 1.67 & 19.40 & 53.07 & 86.70 & 12.495 \\
\hline AC4 & 0.90 & 28.90 & 46.64 & 88.13 & 16.568 \\
\hline AC6 & 0.93 & 27.90 & 29.07 & 89.47 & 9.496 \\
\hline KJ & 1.43 & 11.87 & 16.87 & 27.33 & 4.137 \\
\hline KC & 0.97 & 3.50 & 10.13 & 16.27 & 3.828 \\
\hline KG & 1.63 & 41.48 & 48.00 & 63.00 & 14.560 \\
\hline CD@1\% & 0.564 & 12.654 & 4.743 & 9.061 & \\
\hline
\end{tabular}

were mixed with sample buffer, and boiled in water bath at $95^{\circ} \mathrm{C}$ for $1 \mathrm{~min}$ and allowed to cool at room temperature. In all experiments, $25 \mu \mathrm{g}$ of protein extract was loaded per well of the PAGE gel.

Guaiacol peroxidase enzyme assay: Peroxidase activity was assayed as increase in optical density due to the oxidation of guaiacol to tetra-guaiacol as per the method by Castillo et al., (1984). Absorbance due to the formation of tetra-guaiacol was measured at a time interval of $30 \mathrm{sec}$ up to 1 $\min$ at $470 \mathrm{~nm}$.

Native page analysis for peroxidase isoenzyme analysis: The protein samples (20 $\mu \mathrm{g}$ each) were separated by native gel electrophoresis at $6^{\circ} \mathrm{C}$. For staining, the gel was incubated in a solution containing $0.1 \mathrm{M}$ Potassium phosphate buffer $(\mathrm{pH}$ 6.1), $20 \mathrm{mM}$ Guaiacol and $5.55 \mathrm{mM} \mathrm{H}_{2} \mathrm{O}_{2}$ for $10-20$ min at room temperature until the bands appeared. The gel was then washed with $7.5 \%$ acetic acid and $1 \%$ glycerol to stop the reaction. The isoenzyme bands appeared in brick red color, which were stable for $24 \mathrm{~h}$ and the pattern was photographed.

Superoxide dismutase (SOD) enzyme assay: SOD activity was measured by the method described by Dhindsa et al., (1981) with slight modifications. SOD activity in the protein extracts was monitored by its ability to inhibit photochemical reduction of nitroBlue tetrazolium. The Soluble protein fraction 
$25 \mu \mathrm{g}$, was assayed in a reaction mix of $1 \mathrm{~mL}$, containing $100 \mathrm{mM}$ Phosphate buffer (pH 7.8), 200 $\mathrm{mM}$ Methionine, $2.25 \mathrm{mM}$ NitroBlue tetrazolium chloride (NBT), 3 mM EDTA, $60 \mu \mathrm{M}$ Riboflavin, 1.5 $\mathrm{mM}$ Sodium carbonate. The test tubes containing assay mixture were incubated under light for 15 min and non-illuminated reactions without supernatant served as blank. Absorbance of samples along with the blank was recorded at 560 nm wavelength.

Enzyme unit: One unit of enzyme activity was defined as the quantity of protein required to reduce the absorbance reading of samples to $50 \%$ in comparison with tubes lacking enzymes.

For the in-gel isoenzyme assay for SOD activity, the proteins were separated by Native PAGE as described earlier. The gel was incubated in a staining solution containing 100 per cent NBT (w/v), 0.2 M EDTA (w/v), 0.1M sodium phosphate buffer ( $\mathrm{pH} 7.5)$, and $5 \%$ riboflavin (w/v) for $30 \mathrm{~min}$ until the bands appeared. The isoenzyme bands appeared as white/colourless in a dark Blue background and the isoenzyme pattern was photographed.

Extraction of phenolics and Flavanoids: Phenolics and Flavanoids were extracted by a common protocol, essentially, $100 \mu \mathrm{g}$ of calli was homogenized in $1 \mathrm{ml}$ of $80 \%$ ethanol in a pestle and mortar. The homogenate was centrifuged at $10000 \mathrm{rpm}$ for $20 \mathrm{~min}$, the supernatant was collected and the residue reextracted with five times the volume of $80 \%$ ethanol and re-centrifuged. After this the supernatant was collected and evaporated to dryness and the residue dissolved in $2 \mathrm{ml}$ of distilled water.

Estimation of phenolics: Total phenolics levels was estimated using Folin-ciocalteu reagent (FCR) that results in the formation of a Blue colored complex which is measured at $650 \mathrm{~nm}$ spectrophotometrically (Ainsworth and Gillespie, 2007). In brief, phenolic extract $(0.2 \mathrm{ml})$ was diluted with $3 \mathrm{ml}$ distilled water and $0.5 \mathrm{ml}$ of Folin-ciocalteau reagent was added. The contents were mixed thoroughly. Exactly after $3 \mathrm{~min}, 2 \mathrm{ml}$ of $20 \%$ sodium carbonate was added. Then content were allowed to stand for $1 \mathrm{~min}$ in boiling water bath, cooled and absorbance was measured at 650 $\mathrm{nm}$ against the reagent blank. A standard graph was constructed with Gallic acid which was used as a standard phenolic. The total phenolic concentration present in the test samples were calculated using standard curve and the concentration is expressed as mg phenolics/g fresh weight.

Estimation of flavonoids: Flavanoid extract $(0.2$ ml) was diluted with distilled water to make the

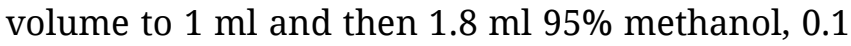
$\mathrm{ml}$ of $1 \mathrm{M}$ sodium acetate and $0.1 \mathrm{ml} 10 \%$ aluminium chloride were added. The absorbance was recorded at $415 \mathrm{~nm}$ using spectrophotometer against the blank. A standard graph was prepared using Rutin as the standard flavonoid. The flavonoid concentration present in the test samples were calculated using standard curve and the concentration is expressed as $\mathrm{mg}$ flavonoid/g fresh weight.

Separation of the Secreted protein fraction: The method to separate the secreted protein fraction was earlier developed by Anil and co-workers. The callus derived suspension cells of the six potato genotypes were placed in sterilized 150-ml flasks containing $20 \mathrm{ml}$ of MS medium, pH 5.8 and subjected to treatments $\mathrm{T}_{0}, \mathrm{~T}_{1}, \mathrm{~T}_{2}, \mathrm{~T}_{3}$ as described above. Appropriate calli derived suspension cells in MS medium were used as control $\left(\mathrm{T}_{0}\right)$. The flask was maintained on a rotary shaker at $160 \mathrm{rpm}$ in the dark at $18^{\circ} \mathrm{C}$ for three days. Following which the callus suspension cells in the beaker were centrifuged at $5000 \mathrm{rpm}$ for $10 \mathrm{~min}$ to separate the cells and the medium. The supernatant (medium) obtained were sequentially centrifuged by using Contricon centrifuge tubes (10kD cut off) in an Eppendorf refrigerated centrifuge until the proteins got sufficiently concentrated. The secreted protein fractions from the different treatments were quantified by Lowry's method as before. The secreted proteins were evaluated for SOD and Peroxidase activity as per the methods elaborated above.

DAB staining for cellular $\mathrm{H}_{2} \mathrm{O}_{2}$ accumulation: The production of hydrogen peroxide $\left(\mathrm{H}_{2} \mathrm{O}_{2}\right)$ in response to pathogen and/or elicitor treatment, was examined in potato calli of 6 genotypes with 3, 3'-diaminobenzidine (DAB) staining method described by Orozco-Cardenas and Ryan (1999) with slight modification. DAB precipitates and turns deep brown in the presence of $\mathrm{H}_{2} \mathrm{O}_{2}$.

The calli subjected to different treatments were placed in $10 \mathrm{ml}$ of DAB staining solution (DAB $1 \mathrm{mg} / \mathrm{ml} \mathrm{DW}, \mathrm{pH} 3.6$ ) for 2 hours to allow the callus to take up the DAB stain. The callus was washed with hot ethanol and the cells were then observed under microscope at $10 \mathrm{X}$ magnification. The dark brown stained cells indicated intracellular accumulation of $\mathrm{H}_{2} \mathrm{O}_{2}$. The total number of cells in a field and the cells stained by DAB were both counted in multiple microscopic fields and percentage cells accumulating $\mathrm{H}_{2} \mathrm{O}_{2}$ was recorded.

\section{Statistical analysis}

Microscopic cell counting for cell viability and Cells accumulating hydrogen peroxide were made with 5 microscopic fields in each slide for all the genotypes and for each of the treatments used, three replications were maintained. The statistical analysis of the data was carried out using Completely Randomised Design (CRD).

The biochemical assays were done in 3 replications for all the genotypes and for each of the treatments used. The statistical analysis of the data was carried out using Completely Randomised Design (CRD). 


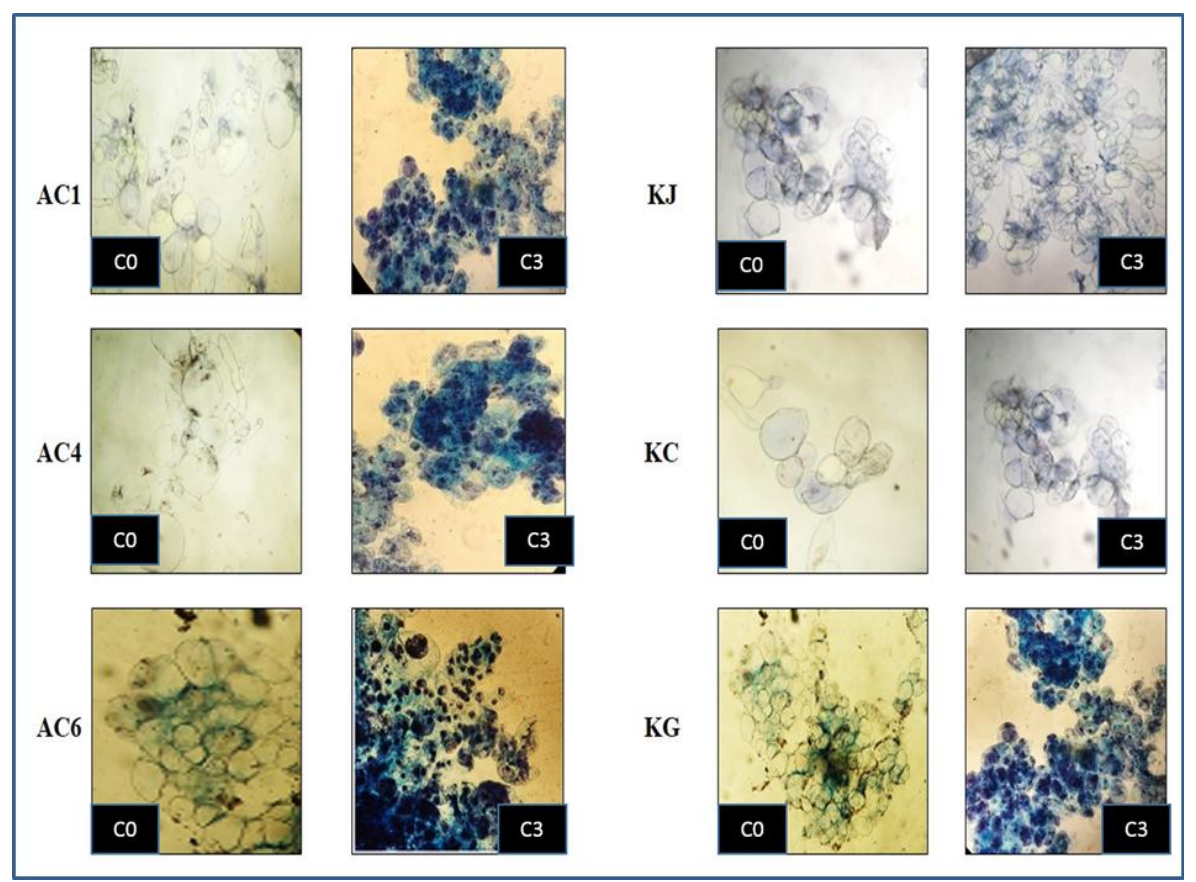

Fig. 3. Trypan Blue stained dead cells in calli grown on phytopathotoxic medium. $\mathrm{C}_{0^{-}}$Control; $\mathrm{C}_{3^{-}} 30$ per cent $\mathrm{CF}$

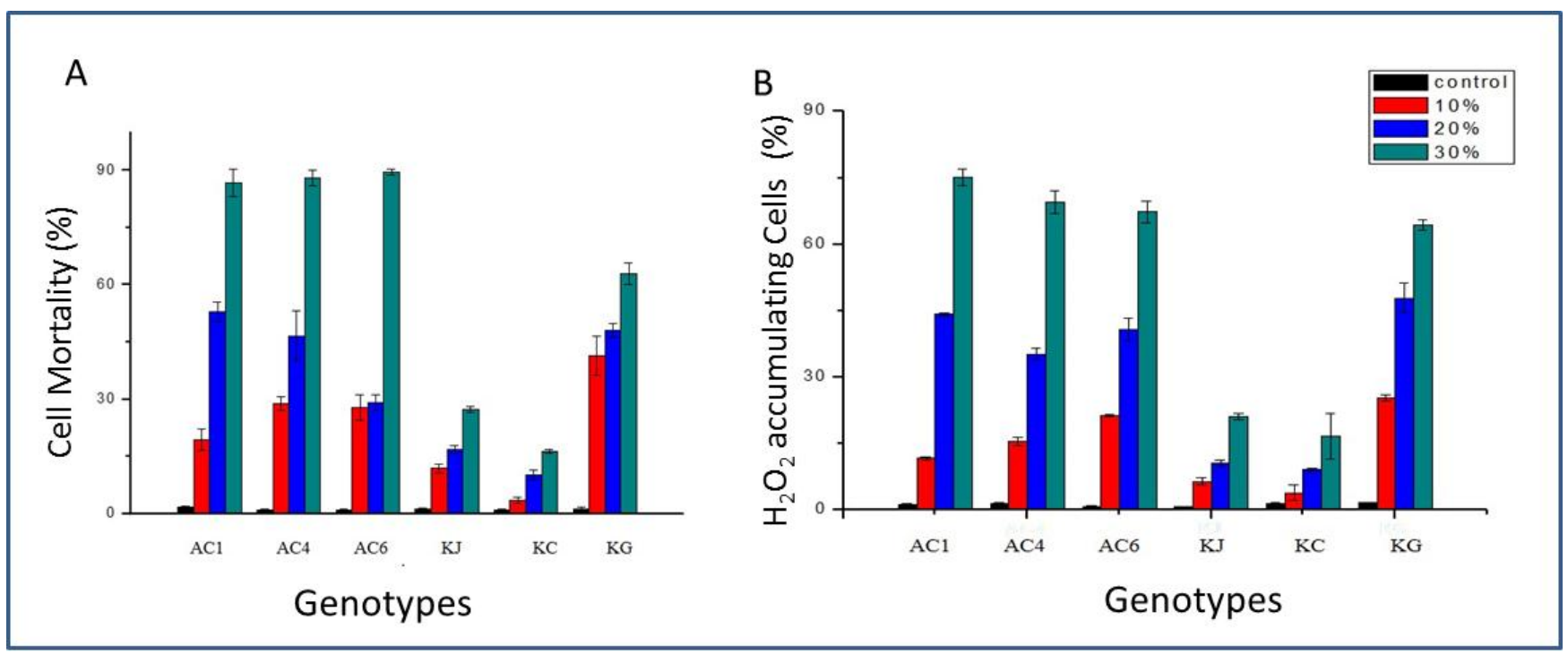

Fig. 4. Effect of growing Calli of potato genotypes on phytopathotoxic medium: A, Percent cell mortality in calli; B, Percent cells accumulating $\mathrm{H}_{2} \mathrm{O}_{2}$. Control, $\mathrm{C}_{0} ; 10 \% \mathrm{CF}, \mathrm{C}_{1} \mathrm{CF} ; 20 \% \mathrm{CF}, \mathrm{C}_{2} ; 30 \% \mathrm{CF}, \mathrm{C}_{3}$.

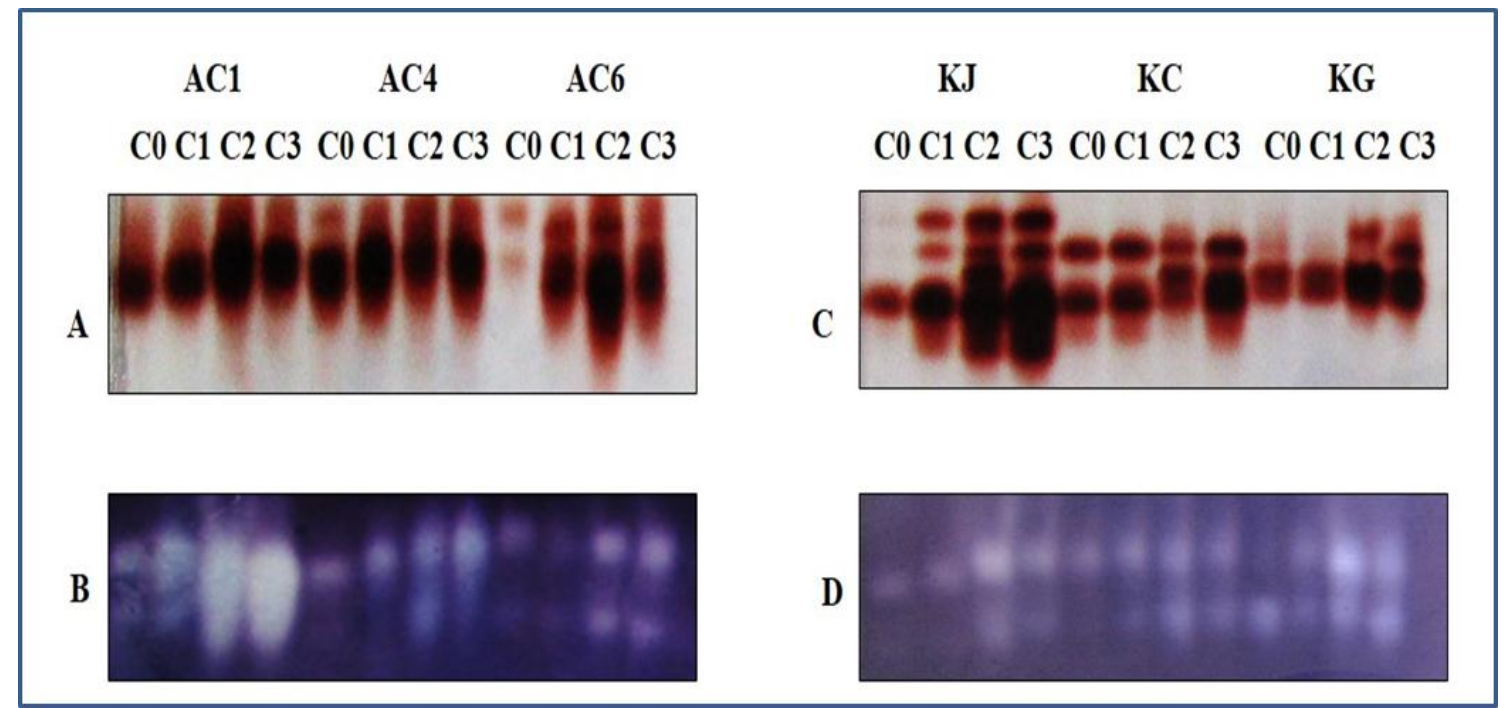

Fig. 5. Calli of six potato genotypes grown on phytopathotoxic medium. A. Control, $\mathrm{C}_{0}$; B. 10 per cent CF, $\mathrm{C}_{1}$; C. 20 per cent CF, $\mathrm{C}_{2}$; D. 30 per cent $\mathrm{CF}, \mathrm{C}_{3}$ 


\section{Results}

Effect of phytopathotoxic medium on callus growth of six potato genotypes

Phytopathotoxic medium was prepared by adding filter sterilized culture filtrate (CF) of Phytophthora infestans to MS medium at a concentration of $0,10,20,30 \%\left(C_{0}, C_{1}, C_{2}, C_{3}\right)$.

Callus of the six genotypes were plated on each of the above treatments $\left(C_{0}-C_{3}\right)$ in petriplates by placing $100 \mu \mathrm{L}$ PCV (packed cell volume) each of callus equidistant from each other. The calli were allowed to grow for a period of 25 days (Fig. 2). The relative visual growth as compared to control plate, cellular defense enzyme activity and cell death were monitored on the $25^{\text {th }}$ day post inoculation.

\section{Cell viability of the callus}

The Percentage mortality in calli cells grown on MS medium containing varying concentrations of Culture Filtrates (CF) of the pathogen was monitored by counting Trypan Blue stained nuclei of cells. The cell death was significantly higher with increase in the concentration of phytotoxic medium (10, 20 and $30 \% \mathrm{CF}, \mathrm{C}_{1}-\mathrm{C}_{3}$ treatments) in all the callus of potato genotypes over control $\left(\mathrm{C}_{0}\right)$ (Table 2) at 25 days post inoculation. The phytopathotoxic medium with $30 \%$ culture filtrate induced highest mortality compared to other treatments. Thus the CF of $P$. infestans had a dose dependent effect on viability of calli cells of all genotypes (Fig. 3, Fig. 4).

When comparisons were made across genotypes, interestingly and surprisingly, the percent cell death was higher in resistant genotypes of potato calli plated on phytopathotoxic medium than susceptible ones. The variations in cell death were significant between the treatments and across the genotypes (Table 2, Fig. 4).

\section{Defense response in calli cells when grown on Phytopathotoxic medium $\left(C_{0}-C_{3}\right)$}

The peroxidase and SOD isoenzyme activity was analyzed in-gel by native PAGE. The gels were processed for SOD and Peroxidase assays as mentioned in materials and method. The banding pattern of peroxidase isozymes varied among genotypes, and peroxidase isoenzyme band intensity increased in calli of all the genotypes with increase in the concentration of phytopathotoxic medium (10, 20 and 30 per cent) (Fig. 5). The SOD activity band intensity increased in the calli of all the six genotypes grown on phytopathotoxic medium (Fig. 5).

\section{Influence of Phytophthora infestans on callus cell viability}

Callus cells were directly exposed to Phytophthora infestans and cell mortality was monitored by Trapan Blue staining followed regularly at $3 \mathrm{hr}$ intervals for a period of $24 \mathrm{~h}$. Potato callus of resistant genotypes AC1, AC4 and KG started dying at $12^{\text {th }} \mathrm{h}$, AC6 at $15^{\text {th }} \mathrm{h}, \mathrm{KJ}$ at $18^{\text {th }} \mathrm{h}$ and KC at $20^{\text {th }} \mathrm{h}$ following exposure to pathogen (Data not shown). The result also revealed that the callus of resistant genotypes were more sensitive to direct exposure to pathogen at the cellular level than the susceptible genotypes.

\section{Effect of Phytophthora infestans or its elicitors on calli cells}

The experiment was conducted with the following treatments:

$\mathrm{T}_{0^{-}}$Callus (Control)

$\mathrm{T}_{1}$ - Callus exposed to Phytophthora infestans (PI)

$\mathrm{T}_{2}$ - callus exposed to diffusilble elicitors (PI inside dialysis bag which is dipped into media containing callus)

\section{$\mathrm{T}_{3}$ - callus exposed to culture filtrate (CF)}

The callus taken per treatment was $200 \mu \mathrm{L} \mathrm{PCV}$. The concentration of $P$. infestans was 20,000 sporangia/mL in treatments $\mathrm{T}_{1}$ and $\mathrm{T}_{2}$. The CF was obtained by centrifuging down a three week old $P$. infestans liquid culture. The clear supernatant was filter sterilized and used as CF. CF was used at $10 \%$ in $\mathrm{T}_{3}$. Potato leaf derived calli of six genotypes thus exposed to different treatments $T_{0}, T_{1}, T_{2}$ and $T_{3}$ for $24 \mathrm{hrs}$ were monitored for cell death by Trypan Blue vital stain as described in materials and methods. The dead cells that are stained Blue were counted under bright field microscope at $10 \mathrm{X}$ magnification.

The result indicate that in the callus of three established resistance genotypes (Anil et al., 2013) viz, AC1, AC4 and $\mathrm{KG}$, the per cent cell death was higher in the treatments with exposure to $P$. infestans as compared to the cell death in established susceptible genotypes, AC6, KJ and KC. Resistant genotypes AC1, AC4 and KG when exposed to the pathogen showed higher level of mortality, i.e. 57.02, 46.80 and $48.21 \%$ respectively as compared to the susceptible genotypes, $\mathrm{KJ}$ and $\mathrm{KC}$, which when exposed to pathogen $\left(\mathrm{T}_{1}\right)$ showed only 19.27 and 12.67 per cent mortality after 24 hour exposure to the pathogen (Table 3). AC6, a susceptible genotype showed slightly higher percentage cell mortality, compared to KC and KJ. However it was significantly lower than the resistant genotypes AC1, AC4 and KG (Table 3).

The results indicate that the calli exposed to the pathogen directly $\left(\mathrm{T}_{1}\right)$ showed higher cell death compared to $\mathrm{T}_{2}$ and $\mathrm{T}_{3}$. However Elicitor treatments also induced significantly higher cell death as compared to control $\left(\mathrm{T}_{0}\right)$. The established resistance genotypes AC1, AC4 and KG exposed to pathogen showed higher cell mortality than the established susceptible genotypes.

\section{Peroxidase activity}

The results show that the peroxidase defense enzyme in the soluble proteins of all the genotypes exposed to pathogen showed increased activity compared to control. The elicitors of pathogen $\left(\mathrm{T}_{2}\right.$, $\mathrm{T}_{3}$ ) also induced POX defense enzyme. However the direct exposure of pathogen (T1) showed 
Table 3: Effect of Phytophthora infestans or its elicitors on calli cell survival

\begin{tabular}{lcccc}
\hline & \multicolumn{4}{c}{ Cell Mortality (\%) } \\
\cline { 2 - 5 } & $\mathbf{T}_{\mathbf{0}}$ & $\mathbf{T}_{\mathbf{1}}$ & $\mathbf{T}_{2}$ & $\mathbf{T}_{3}$ \\
\hline AC1 & 2.47 & 57.02 & 13.4 & 17.14 \\
\hline AC4 & 1.97 & 46.80 & 17.94 & 24.4 \\
\hline AC6 & 2.30 & 38.50 & 14.08 & 20.3 \\
\hline KJ & 1.08 & 19.27 & 5.02 & 7.14 \\
\hline KC & 0.61 & 12.67 & 1.86 & 2.44 \\
\hline KG & 1.63 & 48.21 & 30.44 & 40.56 \\
\hline CD@1\% & 1.164 & 6.375 & 4.946 & 3.574 \\
\hline
\end{tabular}

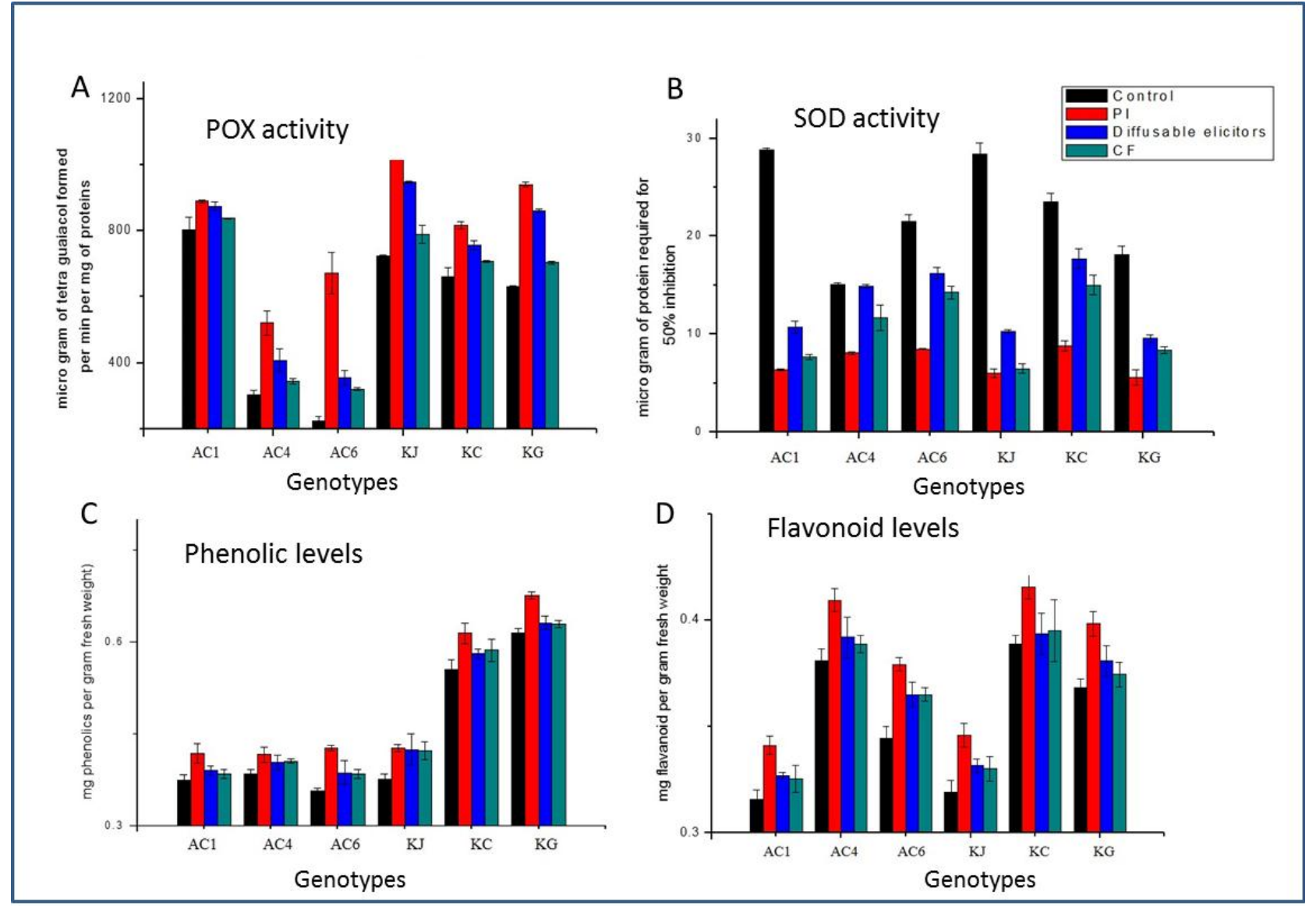

Fig. 6. Defense induction in calli of potato genotypes: A, Peroxidase activity; B, SOD activity; C, Levels of Phenolics; D, Levels of Flavanoids. Control, $\mathrm{T}_{0}$; Direct exposure to Phytopthora infestans, $\mathrm{T}_{1}$; Diffusible elicitor, $\mathrm{T}_{2} ; \mathrm{CF}, \mathrm{T}_{3}$.

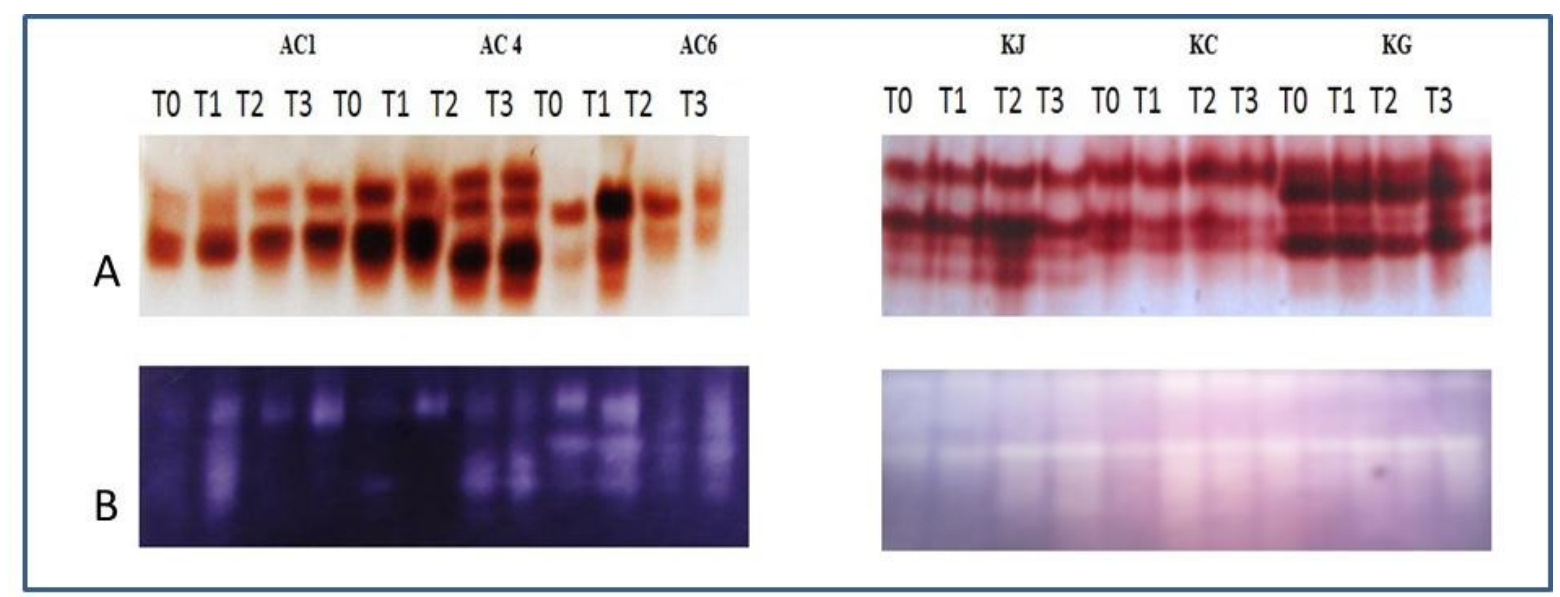

Fig. 7. In gel POX and SOD isoenzyme activity in soluble proteins of calli exposed to P. infestans or its elicitors: A. POX isozymes, B, SOD isozymes, Control, $\mathrm{T}_{0} ; \mathrm{PI}, \mathrm{T}_{1}$; Diffusible elicitor, $\mathrm{T}_{2} ; \mathrm{CF}, \mathrm{T}_{3}$ 
Table 4: Effect of to Phytophthora infestans and its elicitors on Peroxidase activity in calli

\section{Peroxidase Activity}

Genotypes

( $\mu$ g tetra guaiacol/ $\mathrm{min} / \mathrm{mg}$ of protein)

\begin{tabular}{lccccc} 
& $\mathbf{T}_{\mathbf{0}}$ & $\mathbf{T}_{\mathbf{1}}$ & $\mathbf{T}_{\mathbf{2}}$ & $\mathbf{T}_{\mathbf{3}}$ & \\
\hline AC1 & 766.67 & 890.00 & 875.33 & 838.00 & 40.140 \\
\hline AC4 & 303.33 & 521.33 & 409.33 & 344.67 & 124.657 \\
\hline AC6 & 226.00 & 672.00 & 356.00 & 322.00 & 105.859 \\
\hline KJ & 631.33 & 941.33 & 861.33 & 704.00 & 24.809 \\
\hline KC & 662.00 & 816.67 & 757.33 & 708.00 & 79.670 \\
\hline KG & 723.33 & 1023.33 & 947.33 & 790.00 & 104.323 \\
\hline CD@1\% & 64.438 & 94.605 & 99.775 & 49.686 &
\end{tabular}

Table 5: Effect of Phytophthora infestans or its elicitors on Superoxide dismutase activity in calli

\section{SOD activity}

Genotypes

( $\mu$ g of protein required for $50 \%$ inhibition)*

CD@1\%

\begin{tabular}{|c|c|c|c|c|c|}
\hline & & \\
\hline & $\mathbf{T}_{0}$ & $T_{1}$ & $\mathbf{T}_{2}$ & $\mathbf{T}_{3}$ & \\
\hline AC1 & 28.80 & 6.34 & 10.72 & 7.67 & 1.640 \\
\hline AC4 & 15.11 & 8.08 & 14.90 & 11.69 & 3.175 \\
\hline AC6 & 21.52 & 8.48 & 16.24 & 14.27 & 2.578 \\
\hline $\mathbf{K J}$ & 28.42 & 6.05 & 10.30 & 6.47 & 3.138 \\
\hline KC & 23.52 & 8.83 & 17.73 & 15.01 & 4.165 \\
\hline KG & 18.11 & 5.57 & 9.58 & 8.39 & 3.084 \\
\hline CD@1\% & 3.282 & 1.867 & 2.402 & 3.313 & \\
\hline
\end{tabular}

*Smaller values represent higher SOD activity

higher activity in all the six genotypes. The highest induction of POX was recorded in calli of resistance genotypes, $\mathrm{KG}$ and $\mathrm{AC} 1$ with exposure to $P$. infestans (Table 4, Fig 6A). Gel assays showed that $P$. infestans exposure enhanced POX isoenzyme activity in calli of all six genotypes. The direct exposure of calli to the pathogen $\left(T_{1}\right)$ showed higher POX activity. However, diffusible pathogen elicitors $\left(\mathrm{T}_{2}\right)$ or elicitors in CF $\left(\mathrm{T}_{3}\right)$ also induced POX isoenzyme activity in all the genotypes. The resistant genotypes AC1, AC4 and KG showed higher intensity of POX isoenzyme bands than susceptible genotypes (Fig. 7).

\section{Superoxide dismutase (SOD) activity}

The soluble proteins extracted from the calli of all six genotypes with treatments $T_{0}, T_{1}, T_{2}$ and $T_{3}$ were assayed for SOD defense enzyme activity spectrophotometrically and the data are presented in Table 5. The results indicate significant variations in SOD activity among the treatments and also across the genotypes (Fig. 6B). SOD activity increased with $P$. infestans/elicitor exposure in all genotypes as compared to control $\left(\mathrm{T}_{0}\right)$. The highest activity was observed in $\mathrm{KG}$ (Table 5). The SOD isoenzyme activity was analyzed by native PAGE by using NBT as substrate. The SOD activity in calli of all genotypes increased with the pathogen/elicitor exposure over control (Fig. 7). The banding pattern of the isozymes varied among the genotype.

Phenolics and Flavanoid contents in calli exposed $P$. infestans/diffusible elicitors /CF

The exposure of calli of the six genotypes to $P$. infestans leads to the marked increase in phenolic content in all the genotypes over the control $\left(\mathrm{T}_{0}\right)$. The phenolic content was higher in the calli exposed directly to the pathogen $\left(\mathrm{T}_{1}\right)$ than those of other treatments $\left(\mathrm{T}_{2}\right.$ and $\mathrm{T}_{3}$ ) (Fig.6C, Table 6).

\section{Flavonoid content analysis}

The flavonoid content in the callus of all the potato genotypes exposed to $P$. infestans/elictors $\left(\mathrm{T}_{0}, \mathrm{~T}_{1}, \mathrm{~T}_{2}\right.$ and $\mathrm{T}_{3}$ ) shows that there is an increase in flavanoid content in all calli of genotypes in treatments $\mathrm{T}_{1}, \mathrm{~T}_{2}$ and $\mathrm{T}_{3}$ compared to the control $\left(\mathrm{T}_{0}\right)$. The flavonoid content in all the calli exposed to $P$. infestans $\left(\mathrm{T}_{1}\right)$ was relatively higher than other two treatments $\left(\mathrm{T}_{2}\right.$ and $\mathrm{T}_{3}$ ) (Fig. 6D, Table 7).

\section{Analysis of secreted proteins for defense} enzyme activity

Secreted protein of the calli derived suspension cells of six genotypes with treatments $\mathrm{T}_{0}, \mathrm{~T}_{1}, \mathrm{~T}_{2}$ and 
$\mathrm{T}_{3}$ were collected in the surrounding medium, concentrated by repeated centrifugation using centricon centrifugation tubes. The protein thus concentrated was estimated by Lowry's method as described in materials and methods and the protein concentration was calculated by using BSA standard curve and analyzed first by SDS-PAGE (Fig. 8).

\section{Peroxidase isoenzyme activity in secreted protein fraction}

Gel assay shows that the POX isoenzyme activity significantly increased in the secreted protein fraction with direct exposure to $P$. infestans $\left(\mathrm{T}_{1}\right)$ in all the calli of potato genotypes (Fig. 8). POX also increased in secreted protein fraction of calli cells under exposure to diffusible pathogen elicitors $\left(\mathrm{T}_{2}\right)$ and in secreted proteins of calli subjected only to CF exposure $\left(\mathrm{T}_{3}\right)$. The pattern of POX isoenzymes varied among genotypes and in some cases across treatments (Fig. 8).

\section{SOD isoenzyme activity in secreted protein fraction}

Isoenzyme pattern of SOD in the secreted protein fraction from all six genotypes exposed to $P$. infestans/elicitors $\left(\mathrm{T}_{1}, \mathrm{~T}_{2}, \mathrm{~T}_{3}\right)$ shows that the SOD isoenzyme activity significantly increased in the secreted protein fraction with direct exposure to $P$. infestans $\left(\mathrm{T}_{1}\right)$ in all the calli of potato genotypes (Fig. 8). SOD also increased in secreted protein fraction of calli cells under exposure to diffusible pathogen elicitors $\left(\mathrm{T}_{2}\right)$ and in secreted proteins of calli subjected only to CF exposure $\left(T_{3}\right)$. The pattern of SOD isozymes varied among genotypes and in some cases across treatments.

\section{3, 3'-Diaminobenzidine (DAB) staining for $\mathrm{H}_{2} \mathrm{O}_{2}$ accumulation}

To understand why resistant genotypes of potato showed higher cell mortality in calli, percent of cells accumulating $\mathrm{H}_{2} \mathrm{O}_{2}$ was evaluated when challenged with $P$. infestans/elicitors using DAB staining technique. Cell accumulating high $\mathrm{H}_{2} \mathrm{O}_{2}$ stained dark reddish brown in colour, whereas those cells with little or no $\mathrm{H}_{2} \mathrm{O}_{2}$ were colorless or very light brown. The calli of genotypes under study grown for 25 days on increasing concentration of phytopathotoxic medium $\left(\mathrm{C}_{0}-\mathrm{C}_{3}\right)$ (Table 8, Fig. 4B) and directly challenged with the pathogen for $24 \mathrm{hrs}$ (Table 9, Fig. 9), were stained with DAB as per the procedure in Materials and Methods. The result revealed that high accumulation of $\mathrm{H}_{2} \mathrm{O}_{2}$ was predominant in resistance genotypes, AC1, AC4 and KG with higher percent cells accumulating $\mathrm{H}_{2} \mathrm{O}_{2}$ (Table 8, Fig. 4B). Whereas fewer cells of the susceptible genotypes AC6, $\mathrm{KJ}$ and $\mathrm{KC}$ accumulated $\mathrm{H}_{2} \mathrm{O}_{2}$ (Table 8, Fig. 4B) that too at lower levels as indicated by the pale brown staining of cells when directly exposed to the pathogen or when grown on elicitor medium. Direct exposure to pathogen for $24 \mathrm{hrs}$ also showed similar results of higher percent cells with $\mathrm{H}_{2} \mathrm{O}_{2}$ in resistant potato genotypes compared to susceptible genotypes (Table 9, Fig. 9).

\section{Correlation between cell death and hydrogen peroxide accumulation}

Direct linear correlation between cell death and cells accumulating high hydrogen peroxide in the calli cells of six potato genotypes was seen, independent of wild and cultivated genotypes. The genotypes indicated with red color are susceptible genotypes (AC6, KC, KJ) and genotypes in Blue color resistant genotypes (AC1, AC4, KG) (Fig. 9). The Resistant genotypes grouped together with higher percent cells accumulated $\mathrm{H}_{2} \mathrm{O}_{2}$ and higher percent Cell death.

\section{Discussion}

Late blight, caused by Phytophthora infestans, is one of the most devastating diseases of potato, causing yield loss of over $30 \%$ globally. In India, Late Blight has devastating effects on the potato crop, causing yield losses in the plains of India to the tune of over 50\%. Popular cultivars such as Kufri Jyoti, were originally released as a Late Blight resistant variety, is now rendered highly susceptible. Late Blight also affects other economically important Solanaceae family crops like Tomato.

Due to domestication, the cultivated potatoes lost their genetic variation. Wild potato species represents diverse gene pool which have been used traditionally as a source of diverse trait for potato breeding (Hijmans et al., 2007). These wild species can be used to breed potato against biotic stress like Late Blight and abiotic stresses such as salt, heat and cold stresses.

Understanding the molecular mechanisms of defense responses in resistant genotypes can identify novel mechanisms that could be exploited to enhance Late Blight resistance. Anil and Coworkers have earlier investigated nine potato genotypes- six wild type species (Solanum chacoense genotypes- AC1, AC2; S. sparsipillium genotypes AC3, AC4, AC5 and genotype of $S$. spegzinii, AC6) and three potato cultivars (KJ, KC and KG), for their response to Late Blight. Three years (2012-2014) of field testing and laboratory detached-leaf assays show that wild species, $S$. chacoense (AC 1) and S. sparsipillium (AC 4) and the cultivar Kufri Girdhari are highly resistant to Late blight and show heightened defense response. An understanding of resistance response at the cellular level, independent of influences and contributions from the tissue environment of the whole plant would shed light on cellular mechanisms. In vitro cultures can serve as a model system to understand such cellular mechanisms (Anil et al., 2000).

Cells of calli represent dedifferentiated cells and the extent to which their physiology is similar to the whole plant varies between plant species. Calli of a salt-sensitive glycophyte and two salttolerant halophytes are reported to show similar salt sensitivity in culture. On the other hand, 
Table 6: Effect of Phytophthora infestans or its elicitors on Phenolic content of calli

\begin{tabular}{|c|c|c|c|c|c|}
\hline \multirow{2}{*}{ Genotypes } & \multicolumn{4}{|c|}{$\begin{array}{c}\text { Phenolics } \\
\text { (mg phenolics/g FW) }\end{array}$} & \multirow{2}{*}{ CD@1\% } \\
\hline & $\mathbf{T}_{\mathbf{0}}$ & $\mathbf{T}_{1}$ & $\mathbf{T}_{2}$ & $\mathbf{T}_{3}$ & \\
\hline AC1 & 0.36 & 0.43 & 0.39 & 0.41 & 0.010 \\
\hline AC4 & 0.38 & 0.43 & 0.39 & 0.41 & 0.014 \\
\hline AC6 & 0.37 & 0.43 & 0.40 & 0.38 & 0.028 \\
\hline $\mathbf{K J}$ & 0.33 & 0.45 & 0.37 & 0.43 & 0.010 \\
\hline KC & 0.55 & 0.64 & 0.58 & 0.59 & 0.056 \\
\hline KG & 0.61 & 0.68 & 0.63 & 0.63 & 0.037 \\
\hline CD@1\% & 0.031 & 0.031 & 0.029 & 0.037 & \\
\hline
\end{tabular}

Table 7: Effect of Phytophthora infestans or its elicitors on Flavonoid content of calli

\begin{tabular}{|c|c|c|c|c|c|}
\hline \multirow{2}{*}{ Genotypes } & \multicolumn{4}{|c|}{$\begin{array}{c}\text { Flavanoid } \\
\text { (mg Flavanoids/g FW) }\end{array}$} & \multirow{2}{*}{ CD@1\% } \\
\hline & $\mathbf{T}_{0}$ & $\mathbf{T}_{1}$ & $\mathbf{T}_{2}$ & $\mathbf{T}_{3}$ & \\
\hline AC1 & 0.32 & 0.36 & 0.35 & 0.36 & 0.015 \\
\hline AC4 & 0.38 & 0.43 & 0.40 & 0.41 & 0.024 \\
\hline AC6 & 0.33 & 0.41 & 0.38 & 0.38 & 0.005 \\
\hline $\mathbf{K J}$ & 0.32 & 0.38 & 0.36 & 0.37 & 0.014 \\
\hline KC & 0.39 & 0.43 & 0.40 & 0.41 & 0.018 \\
\hline KG & 0.37 & 0.40 & 0.38 & 0.38 & 0.020 \\
\hline CD@1\% & 0.019 & 0.018 & 0.018 & 0.008 & \\
\hline
\end{tabular}

$\begin{array}{llllllll}\text { AC6 } & \mathrm{AC} 4 & \mathrm{ACl} & \mathrm{KC} & \mathrm{KJ} & \mathrm{KG}\end{array}$

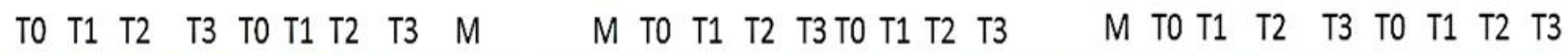
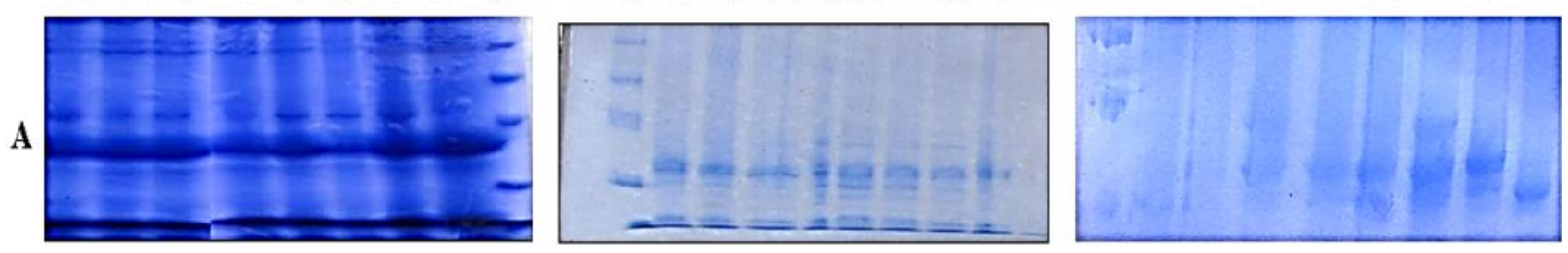

TO T1 T2 T3 TO T1 T2 T

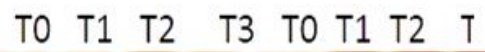

$\begin{array}{llllllll}\text { TO } & \text { T1 } & \text { T2 } & \text { T3 } & \text { TO } & \text { T1 } & \text { T2 } & \text { T3 }\end{array}$
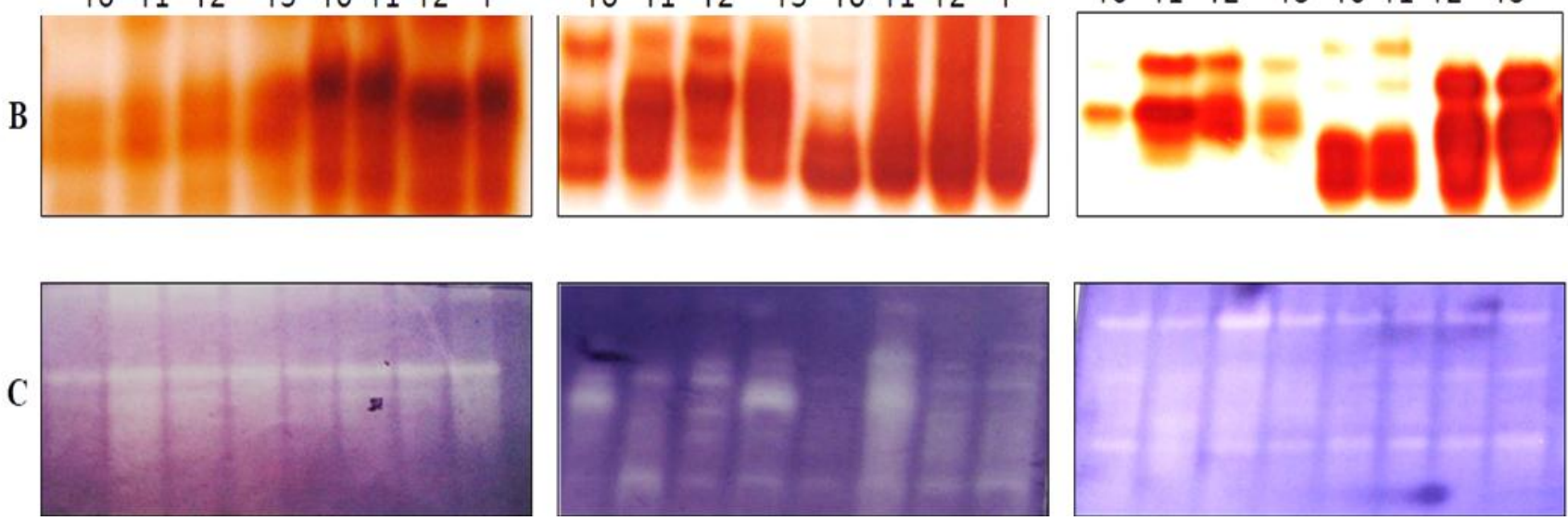

Fig. 8. Secreted protein fraction of Calli of the Potato genotypes: A, SDS- PAGE, B, POX isozyme; C, SOD isozyme banding pattern of AC1, AC4, AC6, KJ, KC and KG for secreted proteins. Control, $\mathrm{T}_{0} ; \mathrm{PI}, \mathrm{T}_{1}$; Diffusible elicitor, $\mathrm{T}_{2} ; \mathrm{CF}, \mathrm{T}_{3}$ 
the callus of salt-tolerant glycophyte, Beta vulgaris exhibited salinity tolerance comparable to the whole plant (Smith and McComb, 1981; Strogonov, 1973). Anil and coworkers have shown that suspension cultures of rice captured the salttolerance characteristics of the cultivars they are derived from (Anil et al., 2007). Thus the cellular mechanisms observed in vitro cell cultures are indicative of the repertoire available to the genotype and can thus serve as a useful model system. Nonetheless, caution needs to be exercised in the extrapolation of the results obtained using isolated cells to the physiology of whole plants. The calli system facilitates the study of cellular mechanisms better, as conditions in the medium can be easily varied and the cells are more amenable to microscopic and cell biology techniques as compared to the whole plant/tissue systems.

In this study leaf derived calli of six potato genotypes, three derived from resistant genotypes (AC1, AC4, KG) and three derived from susceptible genotypes (AC6, KJ, KC), were used as a model experimental system to understand the cellular defense responses. The study has been able to show that the direct contact with pathogen $\left(\mathrm{T}_{1}\right)$, indirect contact with the pathogen (diffusible elicitor, $\mathrm{T}_{2}$ ) and exposure to filter sterilized culture filtrate $\left(\mathrm{T}_{3}\right)$ all had the ability to induce significant defense response in all the six genotypes under study. The study also evaluates pathogen induced changes in secreted protein fraction of the calli. High levels of SOD and POX activity is detected in the secreted protein fraction, indicating that defense response goes beyond the cell itself and spills into the extracellular medium. The surprising observation of this study is the sensitivity of calli of established resistant genotypes to exposure to pathogen or its elicitor, while the susceptible genotypes fared much better under the same biotic stress treatments. Thus this created a paradox wherein low survivability levels at the calli level refuted the high resistance observed at the whole plant, the study attempts to decipher this paradox.

Plant defense mechanisms against pathogens are indeed complex. The plant cell on one hand has to produce ROS as a response to the biotic treat at the same time it has to mitigate pathogeninduced oxidative stress. Generally, a fine intracellular balance between ROS generation and scavenging exists in cells. Plants possess an array of antioxidants that can protect cells from oxidative damage by scavenging ROS (Noctor et al., 1998). The enzymes involved in generation and scavenging ROS include SOD (generates $\mathrm{H}_{2} \mathrm{O}_{2}$ ) and POX (scavenges $\mathrm{H}_{2} \mathrm{O}_{2}$ ), which work together with other enzymes of the ascorbate-glutathione cycle maintain the appropriate balance of ROS (Hernandez et al., 2000). SOD catalyzes the dismutation of $\mathrm{O}_{2}^{-}$to $\mathrm{H}_{2} \mathrm{O}_{2}$ and $\mathrm{O}_{2}$. POX is widely distributed in all higher plants and protects cells against the destructive influence of $\mathrm{H}_{2} \mathrm{O}_{2}$ by catalyzing its decomposition through the oxidation of phenolic.

POX and SOD play a very important role in plant defense response processes. The correlations between aggravation of diseases and enzymes activity are reported to be significant (Silva et al., 2002; 2008). In the current study, significant increases in POX and SOD activities were detected both in spectrophotometric assays as well as in in gel assays that clearly showed enhanced activity of isozymes of calli (Fig. 5, 6, 7) of all genotypes when grown in phytopathotoxic medium $\left(\mathrm{C}_{1}, \mathrm{C}_{2}, \mathrm{C}_{3}\right)$, or when exposed to $P$. infestans $\left(\mathrm{T}_{1}\right)$ or its elicitors $\left(\mathrm{T}_{2}\right.$, $\mathrm{T}_{3}$ ) (Fig. 5, 6, 7).

ROS are often detected in plant-pathogen interactions and are associated with symptom development. $\mathrm{H}_{2} \mathrm{O}_{2}$, a ROS, is generated by the activity of Superoxide dismutase (SOD) that converts a Superoxide anion into $\mathrm{H}_{2} \mathrm{O}_{2} \cdot \mathrm{H}_{2} \mathrm{O}_{2}$ in the whole plant context is produced both within a cell and also in the apoplastic region as one of the primary defenses against pathogen attack. The toxic $\mathrm{H}_{2} \mathrm{O}_{2}$ induces cell death at the site of infection thus curtailing spread of disease, a phenomenon called as hypersensitive response. ROS in general can also act as a second messenger in the cell and play pivotal roles in cell signaling coupling various external stimuli to an appropriate response in plants (Alscher, et al., 2002)

Earlier work (Anil et al., 2013) clearly shows that resistant genotypes have high SOD activity, and accumulated high levels of $\mathrm{H}_{2} \mathrm{O}_{2}$ as compared to susceptible genotypes. This highlights the pivotal role of SOD and $\mathrm{H}_{2} \mathrm{O}_{2}$ in an effective defense mechanism in resistant potato genotypes (Anil et al., 2013). In fact the current study also shows significant enhancement of SOD activity in calli of all genotypes when either grown on phytopathotoxic medium or when directly or indirectly exposed to pathogen or its elicitors (Table 5). SOD activity was induced and the activity was highest in the resistant genotype KG followed by AC1 and AC4. However, susceptible genotypes too showed enhanced SOD activity with the biotic stress imposed in this study. Among the treatments it was direct exposure to Phytophthora infestans $\left(\mathrm{T}_{1}\right)$ that induced highest degree of SOD activity, followed by exposure to filter sterilized CF $\left(\mathrm{T}_{3}\right)$ and indirect exposure to live pathogen $\left(\mathrm{T}_{2}\right)$ (Table 5, Fig. 5, 6, 7).

Interestingly, this study also shows that SOD is secreted out into the extracellular medium and higher levels of secreted SOD activity was detected when exposed to P. infestans/elicitors (Fig. 8). A plasma membrane bound enzyme (NADP dependent Reactive Oxidative burst homologe D) is implicated in this rise in ROS levels in the apoplastic fluid. This study along with an earlier study of secreted proteins with in vitro grown whole plants (Anil, unpublished) show that SOD is secreted out of the cell, suggesting its role in defense response in the apoplastic environment, 
Table 8: Accumulation of Hydrogen peroxide in the calli grown on phytopathotoxic medium

\begin{tabular}{cccccc}
\hline \multirow{2}{*}{ Genotypes } & \multicolumn{3}{c}{ Cells accumulating $\mathbf{H}_{\mathbf{2}} \mathbf{O}_{\mathbf{2}} \mathbf{( \% )}$} & CD@1\% \\
\cline { 2 - 5 } & $\mathbf{C}_{\mathbf{0}}$ & $\mathbf{C}_{\mathbf{1}}$ & $\mathbf{C}_{2}$ & $\mathbf{C}_{\mathbf{3}}$ & 8.961 \\
\hline AC1 & 1.64 & 11.63 & 44.17 & 75.17 & 7.250 \\
\hline AC4 & 1.61 & 15.50 & 35.13 & 69.50 & 7.873 \\
\hline AC6 & 0.83 & 21.30 & 40.70 & 56.53 & 3.229 \\
\hline KJ & 0.80 & 6.43 & 10.57 & 21.10 & 2.732 \\
\hline KG & 1.65 & 4.63 & 9.13 & 11.87 & 8.430 \\
\hline CD@1\% & 1.63 & 25.20 & 47.87 & 64.30 & 7.488 \\
\hline
\end{tabular}

Table 9: Hydrogen peroxide accumulation in calli exposed to Phytophthora infestans for 24 hours

\begin{tabular}{cc}
\hline Genotypes & ${\mathbf{\% ~} \mathbf{H}_{\mathbf{2}} \mathbf{O}_{\mathbf{2}} \text { accumulated cells }}$ \\
\hline $\mathrm{AC} 1$ & 44.17 \\
\hline $\mathrm{AC} 4$ & 40.70 \\
\hline $\mathrm{AC} 6$ & 35.13 \\
\hline $\mathrm{KJ}$ & 10.57 \\
\hline $\mathrm{KC}$ & 4.77 \\
\hline $\mathrm{KG}$ & 47.87 \\
\hline $\mathrm{CD} @ 1 \%$ & 9.800
\end{tabular}

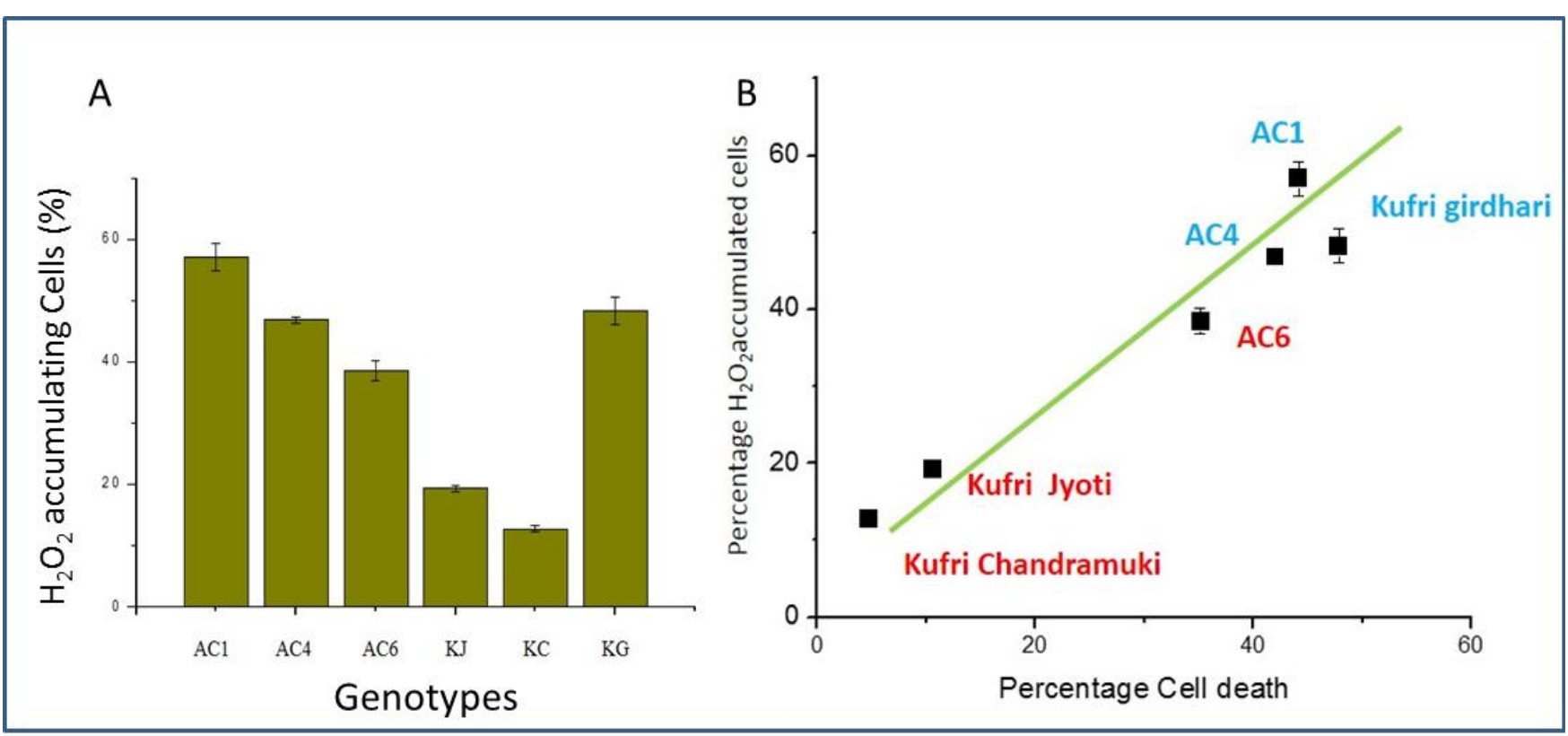

Fig. 9. Percent cells accumulating hydrogen peroxide in calli of six potato genotypes exposed to Phytophthora infestans

probably by creating a toxic environment to the incoming pathogen.

Peroxidases participate in a variety of plant defense mechanism and play an important role in the host pathogen interactions. Hydrogen peroxide is often supplied as an oxidative burst. Enzymes, peroxidase and catalases, are capable of eliminating the hydrogen peroxide formed during non-enzymatic or enzymatic dismutation (Chkhubianishvili et al., 2011). In addition, peroxidases (POX) play other important roles with an increased peroxidase activity being associated with environmental stresses on plants. POX is known in lignin synthesis and oxidation of the endogenous Indole acetic acid. Plant peroxidases act as catalysts for the polymerization of phenolic compound to form suberin and lignin in the cell wall, which act as barrier for the entry of pathogen (Kavitha and Umesha, 2008). 
In the current study, calli from all six genotypes showed an induction of Peroxidase activity with direct exposure to $P$. infestans $\left(\mathrm{T}_{1}\right)$ or its diffusible elicitor $\left(\mathrm{T}_{2}\right)$. The exposure to filter sterilized CF $\left(\mathrm{T}_{3}\right)$ also showed POX induction but significantly lower than $\mathrm{T}_{1}$ and $\mathrm{T}_{2}$ (Table 4, Fig. 5, 6, 7). The general induction of POX corroborated with our earlier observations with the whole plant indicating that this is a common response mechanism to pathogen challenge in both susceptible and resistant genotypes of potato (Table 4). Interestingly, the calli cells show more than ten-fold higher basal peroxidase activity as compared to leaf tissues. The reason for this high basal peroxidase activity, is as of now, unclear. The results corroborate earlier studies that show inductions of POX isoforms at level of activity and gene expression correlate to disease resistance (Zhang et al., 2009). Peroxidase activity was higher in resistant tomato cultivars than in susceptible cultivars after inoculation with the bacterial spot pathogen Xanthomonas axonois $p v$. vesicatoria (Kavitha and Umesha, 2008).

The current study evaluated the peroxidase activity in the secreted proteins of calli cells and found induction of peroxidase activity and changes in isozyme pattern in the secreted protein fraction when the cells where exposed directly or indirectly to $P$. infestans $\left(\mathrm{T}_{1}, \mathrm{~T}_{2}\right)$ or to the filter sterilized CF $\left(\mathrm{T}_{3}\right)$ (Fig. 8). This data correlated with our earlier findings that root extruded secretory proteins also accumulate higher POX when exposed to the pathogen (Anil, unpublished observation). The increase in secreted peroxidase from calli cells when challenged with pathogen has relevance at the whole plant scenario, peroxidases play role in lignification and suberization and thickening of cell wall, which in itself is a significant defense response. Indeed, we have earlier observed in the leaves of potato plants, callose formation and wall thickening around the infection site is a mechanism especially present in resistant genotypes (Anil et al 2013). Peroxidases in the extracellular environment may also play a $\mathrm{H}_{2} \mathrm{O}_{2}$ scavenging role, maintaining adequate levels of ROS in the extracellular medium in case of callus cells, and in the apoplastic fluid in case of the whole plant.

The secondary metabolites phenolics and flavonoids play important roles in defense response in plants. Comparative analysis of the genotypes and $P$. colocasiae infection showed that the phenol content was highest in the resistant genotypes than the susceptible genotypes. Phenolics act as substrates for the synthesis of compounds involved in disease resistance, like pterocarpanphytoalexins and hydroxycinnamic acid esters (Dixon and Lamb, 1990). Phenolics also facilitate synthesis of lignins and suberins at the site of infection, which act as a barrier to the penetration of the pathogen (Ebel and Grisebach, 1988).
Flavonoids are very important in plant resistance against pathogenic fungi. Flavonoids quench ROS generated both by the pathogens and the plant as a response to infection. Flavonoids play role in tightening of the plant structures such as walls and tissues by modulating auxin (IAA) activity, which can lead to the promotion of callose and tylose formation and closure of the vascular system to prevent pathogen spread (Beckman, 2000). They also inhibit the cell wall degrading enzymes of pathogens (Treutter, 2005) and have inhibitory effects on spore development and hyphae elongation and microbial adhesion.

Thus Flavanoid and phenolics contribute to resistance in multiple important ways in different plant species. In potato plants our earlier study shows enhancement of flavonoids and phenolics with $P$. infestans challenge. The current study corroborates the observation at the whole plant level as both flavonoid and phenolic levels rise significantly across the calli of genotypes tested. Highest levels of phenolics was detected in the resistant cultivar Kufri girdhri (Table 6, 7). The levels of phenolics and flavanoids varied across the treatments in each of the genotype as well, with highest levels observed with direct exposure to pathogen (Fig. 6). Phenolics play a role in lignification and in the production of phytoalexins. Flavanoids also contribute to wall thickening by callose formation. Our earlier observation with whole potato plants clearly shows wall thickening by callose formation around the infection site is a mechanism predominantly present in resistant genotypes (Anil et al., 2013). Thus the induction of phenolics and flavonoids in calli when exposed to $P$. infestans reflects the repertoire of defense response mechanism that is available to the whole plant. The induction of SOD, POX and secondary defense metabolites in callus also suggest the callus system can be an effective model system to dissect the repertoire of cellular defense mechanisms available to the plants. In fact the culture filtrate elicitors also were toxic enough to induce cell death with time, but more importantly they were able to induce a robust defense response almost comparable to that observed with exposure to $P$. infestans.

\section{Evaluation of cell viability of callus genotypes exposed to $P$. infestans}

Thus it can be inferred, that the calli cells of potato genotypes retained much of the repertoire of defense responses of the whole plant. They robustly responded at a biochemical level by inducing SOD, POX, flavonoids and phenolics, also inducing secreted defense enzyme activity in the surrounding media when challenged with Phytophthora infestans $\left(\mathrm{T}_{1}\right)$ or its elicitors $\left(\mathrm{T}_{2}, \mathrm{~T}_{3}\right)$.

Calli cells of resistant genotypes survived poorly when grown on phytopathotoxic medium, or when exposed to pathogen or its elicitors (Table 2). This was an unexpected observation, which was reconfirmed by following cell death of calli at 
regular intervals over a period of two days postexposure to $P$. infestans. The data clearly suggest that susceptible genotypes especially among the cultivars survived exposure to $P$. infestans to a greater extent compared to resistant genotypes in the period monitored. The experiments pertaining to cell viability thus made clear that when exposed to pathogen, resistance at the whole plant level negatively correlated with cell survival at the cell culture level. To make sense of this difficult paradox, we hypothesized that the resistant genotypes could be producing higher levels of $\mathrm{H}_{2} \mathrm{O}_{2}$ as part of a robust hypersensitive response, levels that could be toxic to the cells and went on to test the hypothesis.

Hydrogen peroxide, a reactive oxygen species (ROS), plays an important role in plant defense responses (Christensen et al.,2001). To examine the role of plant $\mathrm{H}_{2} \mathrm{O}_{2}$ accumulation in cells, the percentage of cells accumulating high $\mathrm{H}_{2} \mathrm{O}_{2}$ in the calli of six genotypes was evaluated post $24 \mathrm{hrs}$ of exposure to $P$. infestans using the DAB staining method. A higher percentage of cells stained strongly with DAB, indicating high $\mathrm{H}_{2} \mathrm{O}_{2}$ accumulation, in calli of resistant potato genotypes AC1, AC4 and KG (Fig. 9, Table 8, and 9). The result indicates that calli cells of resistant genotypes accumulate higher levels of $\mathrm{H}_{2} \mathrm{O}_{2}$, as part of a hypersensitive response; the cells die as $\mathrm{H}_{2} \mathrm{O}_{2}$ is toxic to the cells. Indeed, a correlation analysis (Fig. 9) by plotting percentage cell death as a function of percentage cells accumulating $\mathrm{H}_{2} \mathrm{O}_{2}$ clearly shows a linear correlation between these two parameters, which is found to be independent of ploidy (Wild $2 \mathrm{n}$, Cultivars $4 \mathrm{n}$ ). In both, wild and cultivated species, in the resistant genotype high percentage $\mathrm{H}_{2} \mathrm{O}_{2}$ accumulating calli correlated with high percent Cell death and vice versa for susceptible genotypes.

At the whole plant level hypersensitive response leads to cell death which restricts the spread of pathogen after infection. In the callus of resistance genotypes AC1, AC4, and KG, exposure to pathogen led to higher cell death. The hypersensitive response is a very effective defense mechanism in plants, the same robust response in an in vitro cell system lead to cell death of the dedifferentiated cell cultures. This study thus shows that what is an efficient mechanism of plant survival at the tissue/whole plant level, is reflected as a negative outcome (cell death) in the callus cells. Thus $\mathrm{H}_{2} \mathrm{O}_{2}$ induced cell death can be considered a marker or indicator of disease resistance of the genotype. Thus this study for the first time, uses callus cultures as a model system in demonstrating the toxic effect of robust $\mathrm{H}_{2} \mathrm{O}_{2}$ generation (as a result of interplay of SOD and ROS scavenging enzymes) on the cells of resistant potato genotypes. The potato callus model can be utilized to dissect and further understand cellular defense response including signaling pathways, second messenger, gene expression patterns and changes in membrane potential.

\section{Acknowledgements}

We thank CPRI, Shimla for providing the wild and cultivated genotypes of potato used in this study. This work was supported by the Innovative Young Biotechnologist Award (IYBA), Department of Biotechnology, Government of India to VSA.

\section{Conflict of Interest}

The authors have declared that there is no conflict of interest.

\section{References}

Ainsworth, E. A., and K. M. Gillespie. 2007. Estimation of total phenolic content and other oxidation substrates in plant tissues using Folin-Ciocalteu reagent. Nature Protocols 2: 875 - 877. https://doi.org/10.1038/nprot.2007.102

Alscher, R. G., N. Erturk, and L. S. Heath. 2002. Role of superoxide dismutase (SODs) in controlling oxidative stress in plants. Journal of Exp. Bot 53: 1331-1341. https://doi.org/10.1093/jexbot/53.372.1331

Anil, V, S., A. C. Harmon, and S. K. Rao. 2000. Spatiotemporal accumulation and activity of calciumdependent protein kinases during embryogenesis, seed development, and germination in sandalwood. Plant Physiol. 122: 1035-1043. https://doi.org/10.1104/pp.122.4.1035

Anil, V. S., H. Krishnamurthy, and M. K. Mathew. 2007. Limiting Cytosolic $\mathrm{Na}^{+}$Confers Salt Tolerance to Rice Cells in Culture: A Two-Photon Microscopy Study of SBFI Loaded Cells. Physiologia Plantarum 129: 607-621. https://doi.org/10.1111/j.13993054.2006.00854.x

Anil, V. S., Venkatesh, and P. Gowda. 2013. Defense responses in Potato genotypes against Late Blight pathogen Phytopthora Infestans. National Conference on Crop improvement and adaptive strategies to meet challenges of climate change, GKVK, Bangalore, Feb 22-24.

Asada, K., and M. Takahashi. 1987. Production and scavenging of active oxygen in photosynthesis. In : D. J. Kyle, C. B. Osmond, C. J. Amtzen, Eds, Photoinhibition (Topics in Photosynthesis), Vol 9. Elsevier, Amsterdam, pp 227-287.

Beckman, C. H. 2000. Phenolic-storing cells: keys to programmed cell death and periderm formation in wilt disease resistance and in general defense responses in plants. Physiol. Mol. Plant Pathol., 57:101-110. https://doi.org/10.1006/pmpp.2000.0287

Castillo, F. I., I. Penel, and H. Greppin. 1984. Peroxidase release induced by ozone in Sedum album leaves. Plant Physiol., $\quad 74:$ 846-851. https://doi.org/10.1104/pp.74.4.846

Caten, C. E., and J. L. Jinks 1968. Spontaneous variability of single isolates of Phytophthora infestans. I. Cultural variation. Can. J. Bot., 46: 329-332.

Chaman, M. E., L. J. Corcuera, G, E. Zuniga, L. Cardemil, and V. H. Argandona. 2001, Induction of soluble and cell wall peroxidases by aphid infestation in barley. L. Agric Food Chem. 49: 2249-2253. https://doi.org/10.1021/jf0011440 
Chkhubianishvil, I. E., N. Kacharava, Z. Badridze, S. Chanishvili, and T. Kurdadze, 2011. Activity of Peroxidase, Catalase and Content of Total Proteins in Leaves of some Herbaceous Plants of High Mountains of the Caucasus. Bull. Georg. Natl. Acad. Sci. 5: 96-101.

Christensen, J. H., S. Overney, S. Rohde, W. A. Diaz, G. Bauw, P. Simon, M. Van montagu., and W. boerjan. 2001. The syringaldazine-oxidizing peroxidase PXP 3-4 from poplar xylem: cDNA isolation, characterization and expression. Plant Mol. $\quad$ Biol., 47: 581-593. https://doi.org/10.1023/A:1012271729285

Dat, J., S. Vandenabeele, E. Vranova, M. Van Montagu, D. Inze, and F. Van Breusegem. 2000. Dual action of the active oxygen species during plant stress responses. Cell. Mol. Life Sci., 57: 779-795. https://doi.org/10.1007/s000180050041

Dhindsa, R. H., R. Plumb-dhindsa, and T. A. Thorpe. 1981. Leaf senescence correlated with increased level of membrane permeability, lipid peroxidation and decreased level of SOD and CAT. J. Exptal. Bot., 32: 93-101. https://doi.org/10.1093/jxb/32.1.93

Dixon, R. A., and C. J. Lamb. 1990. Molecular communication in interactions between plant and microbial pathogens. Ann. Rev. Plant Physiol. Plant Mol. Biol., 41: 339-367. https://doi.org/10.1146/annurev.pp.41.060190.002011

Ebel, J., and H. Grisebach. 1988. Defense strategies of soybean against the fungus Phytophthora megasperma: a molecular analysis. Trends in Biochemical Sci., 13: 23-27. https://doi.org/10.1016/0968-0004(88)90014-X

Gechev, T. S., F. V. Breusegem, J. M. Stone, I. Denev, and C. Loloi. 2006. Reactive oxygen species as signals that modulate plant stress responses and programmed cell death. Bioessays 28: 1091-1101. https://doi.org/10.1002/bies.20493

Grant, J. J., and G. J. Loake. 2000. Ole of reactive oxygen intermediates and cognate redox signaling in disease resistance. Plant Physiol. 124: 21-29. https://doi.org/10.1104/pp.124.1.21

Heath, M. C. 2000. Hypersensitive response-related death. Plant Mol. Biol., 44: 321-334. https://doi.org/10.1023/A:1026592509060

Heng-Moss, T. M., G. Sarath, F. Baxendale, D. Novak, S. Bose, N. Xinhi, and S. Quisenberry. 2004. Characterization oxidative enzyme changes in buffalo grasses challenged by Blissus occiduus. J. Econ. Entomol. 97: 1086-1095. https://doi.org/10.1093/jee/97.3.1086

Hernandez, J. A., A. Jimenez., P. Mullineaux, and Sevilla, F. 2000. Tolerance of pea (Pisum sativum L.) to long-term salt stress is associated with induction of antioxidant defenses. Plant Cell Environ. 23: 853-862. 3040.2000.00602.x https://doi.org/10.1046/j.1365-

Hijmans, R. J., T. Gavrilenko, S. Stephenson, J. Bamberg, A. Salas, and D. M. Spooner. 2007. Geographical and environmental range expansion through polyploidy in wild potatoes (Solanum section Petota). Glob. Ecol. Biogeogr. 16: 485-495. https://doi.org/10.1111/j.1466-8238.2007.00308.
Kavitha, R., and S. Umesha. 2008. Regulation of defense-related enzymes associated with bacterial spot resistance in tomato. Phytoparasitica 36: 144. https://doi.org/10.1007/BF02981327

Lamb, C., and R. A. Dixon. 1997. The oxidative burst in plant disease resistance. Annu Rev Plant Physiol. Plant Mol. Biol. 48: 251-275. https://doi.org/10.1146/annurev.arplant.48.1.251

Lowry, D. H., N. J. Rosebrough, A. L. Farr, and J. L. Randall. 1951. Protein measurement with Folinphenol reagent. Biol. Chem. 193: 265-275.

Mittler, R., and E. Lani. 1996. Sacrifice in the face of foes: Pathogen-induced programmed cell death in plants. Trends Microbiol. 4: 10-15. https://doi.org/10.1016/0966-842X(96)81499-5

Murashige, T., and F. Skoog. 1962. A revised medium for rapid growth and bioassays with tobacco tissues cultures. Physiol. Plant. 15: 473-497. https://doi.org/10.1111/j.13993054.1962.tb08052.x

Noctor, G., I. A. M. Aris, L. Jouanin, K. J. Kunert, H. Rennenberg, and C. H. Foyer. 1998. Glutathione: biosynthesis, metabolism and relationship to stress tolerance explored in transformed plants. J. Exp. Bot., 49: 623-647. https://doi.org/10.1093/jxb/49.321.623

Orozco-Cardenas, M., and C. A. Ryan. 1999. Hydrogen peroxide is generated systemically in plant leaves by wounding and system in via the octadecanoid pathway. Proc. Natl. Acad. Sci. USA. 96:

6553-7. https://doi.org/10.1073/pnas.96.11.6553

Silva, M. C., M. Nicole., L. Guerra-Guimarães, and C. J. Rodrigues Jr. 2002. Hypersensitive cell death and post-haustorial defence responses arrest the orange rust (Hemileia vastatrix) growth in resistant coffee leaves. Physiol. Mol. Plant Pathol. 60: 169-183. https://doi.org/10.1006/pmpp.2002.038

Silva, M. C., L. Guerra-Guimarães, A. Loureiro, M. R. Nicole. 2008. Involvement of peroxidases in the coffee resistance to orange rust (Hemileia vastatrix). Physiol. Mol. Plant Pathol. 72: 29-38. https://doi.org/10.1016/j.pmpp.2008.04.004

Smith, M. K., and J. A. MCCOMB. 1981. Effect of $\mathrm{NaCl}$ on the growth of whole plants and their corresponding callus cultures. Aust. J. Plant Physiol. 8: 267-275. https://doi.org/10.1071/PP9810267

Strogonov, B. P. 1973. Structure and Function of Plant Cells in Saline Habitat, p. 284, Wiley, New York and Toronto. https://doi.org/10.1080/00380768.2001.10408411

Treutter, D. 2005. Significance of flavonoids in plant resistance and enhancement of their biosynthesis. Plant Biol., 7: 581-591. https://doi.org/10.1055/s-2005873009

Zhang, Y., S. Xu, P. Ding, D. Wang, Y. T. Cheng, J. He, M. Gao, F. Xu, Y. Li, and Z. Zhu. 2009. Control of salicylic acid synthesis and systemic acquired resistance by two members of a plant-specific family of transcription factors. Proc. Natl. Acad. Sci. USA. 107: 18220-18225. https://doi.org/10.1073/pnas.1005225107. 